$\underline{\text { Article }}$

\title{
Whither WIR (Redux)?
}

\author{
Lorraine Eden ${ }^{1}$ \\ 1 Texas A\&M University, USA \\ Keywords: grand challenges, big questions, foreign direct investment policy, unctad, world investment report \\ https://doi.org/10.46697/001c.18029
}

\section{AIB Insights}

Vol. 20, Issue 4, 2020

\begin{abstract}
The year 2020 marks the 30th anniversary of the World Investment Report (WIR), an UNCTAD publication that examines national, regional, and worldwide trends in foreign direct investment and foreign investment policies. I look back briefly at the first 30 WIRs and then look forward, asking: What next? Whither WIR? I argue that upcoming WIRs should address a mix of Big Questions and Grand Challenges and provide a baker's dozen list of 13 possible themes.
\end{abstract}

The year 2020 will be long remembered for many events, the most important of which will almost certainly be the COVID-19 pandemic and worldwide recession we are still experiencing. For international business scholars and policymakers, the year 2020 will be also remembered as the $30^{\text {th }}$ anniversary of the World Investment Report (WIR), which since 1991 has been written and published by UNCTAD's Division of Investment and Enterprise (DIAE). In this article, I look back briefly at the first 30 years of WIRs and then look forward, asking: What next? Whither WIR? I argue that the WIR theme chapters should address a mix of Big Questions and Grand Challenges (Buckley, Doh, \& Benischke, 2017) over the next 10 years and provide 13 possible themes.

\section{WIR@30: A BRIEF LOOK BACK}

In case there are international business (IB) scholars and students who are unfamiliar with WIR (I suspect the number in this category is small but nonzero), a brief overview may be helpful. The Division on Investment and Enterprise (DIAE) ${ }^{1}$ plays a central role within UNCTAD in terms of its responsibility for analyzing the roles played by investment and business enterprises with respect to developing countries. DAIE considers the World Investment Report to be one of its two flagship activities; the other is the World Investment Forum (UNCTAD, 2019: 4). Together with its two flagships, DIAE publishes between 30 and 50 research publications yearly including its own journal, Transnational Corporations: Investment and Development. ${ }^{2}$
The WIRs have had three leaders or editors-in-chief over their first 30 years. Karl Sauvant created the World Investment Report in 1991 and led the first 15 editions. Anne Miroux, who had worked with Karl on earlier WIRs, was the team leader for the 2005-2009 WIRs. James Zhan has led all the WIRs from 2010 forward. ${ }^{3}$ All of the 30 WIRs have been organized around three sections: (1) recent global and regional trends in FDI, (2) a "theme" chapter, and (3) general and theme-related policy implications. The book is accompanied by an Overview (Executive Summary), a separate (and useful) publication that summarizes the main points in the three sections. The Web Appendix to this article provides a list of all 30 volumes with their titles identifying the report's theme for that year.

In “Whither WIR?” (Eden, 1996: 155), I assessed the first five years of WIRs and concluded that the WIR was "On course, full steam ahead." I see no reason - 24 years later to change my assessment. I believe the WIR series has made a valuable contribution to the literature on MNEs ${ }^{4}$ over the past 30 years, for at least the following four reasons.

First, the Reports provide annual, detailed information and analysis of MNEs, FDI, and FDI policies that is hard to match, either in depth or breadth, anywhere else. One underlying reason for this strength is that DIAE can request with a very high success rate - data from national governments worldwide; thus, the WIRs are often based on unique datasets created in-house by DAIE through surveys, phone calls, and other requests.

Second, DIAE has developed and nurtured a strong two-

\footnotetext{
1 See https://unctad.org/en/pages/DIAE/DIAE.aspx. The division's name, location and activities have changed over the years.

2 https://unctad.org/en/Pages/DIAE/DIAE Publications - Bibliographic Index/Transnational_Corporations_Journal.aspx

3 See Sauvant (2020), Miroux (2020) and Zhan (2020) for WIR histories and analyses.

4 From the time of its establishment in December 1964, UNCTAD has used the term "transnational corporations (TNCs)" instead of "multinational enterprises (MNEs)", primarily for political reasons. My own view is that the term "TNC" suffers from two problems: not all MNEs are "transnational" (globally integrated) nor are they all "corporations" (privately owned and incorporated entities). The term "MNC" suffers from the second problem. The term "MNF" also fails because MNEs consist of more than one firm. The term "MNE", on the other hand, is both broader and more accurate (multinational + enterprise) and thus preferable. WIR began using the term "MNE" a few years ago.
} 
Table 1: Eden's Baker's Dozen Wish List of WIR Themes

\begin{tabular}{|c|l|}
\hline \multicolumn{2}{|l|}{ Big Questions } \\
\hline 1 & Digital Economy Firms and Business Models \\
\hline 2 & Changing Nature of Work in Digital Economy \\
\hline 3 & Factfulness/Big Data \\
\hline 4 & Evidence-based policy making (EBPM) \\
\hline 5 & Private-Public Partnerships (PPPs) \\
\hline 6 & Social Responsibility of Business \\
\hline Grand Challenges & \\
\hline 7 & SDGs 1 \& 10: Poverty and Income Inequality \\
\hline 8 & SDG 5: Gender Equality \\
\hline 9 & SDG 13: Climate Action \\
\hline 10 & Fragility, Conflict, and Violence \\
\hline 11 & Corruption \\
\hline 12 & Shocks and Responses in a VUCA World \\
\hline 13 & A More Protectionist World \\
\hline
\end{tabular}

way relationship between DIAE staff and IB scholars, creating bi-directional knowledge-based spillovers that have benefitted both sides. ${ }^{5}$ The themes for the various WIRs over the 30-year history of the series reflect that bi-directional relationship (see Buckley, 2020a). Over time the links between AIB and DIAE have also strengthened and matured; the most recent example being the new partnership between DAIE and AIB, the UNCTAD-AIB Award for Research on Investment and Development, where the selection committee for the first award consisted of both AIB Fellows and DIAE staff. Zhan, in separate correspondence (Sept. 7, 2020) with the author, noted that "one of the objectives of the collaboration with AIB is to stimulate more policy-relevant IB research.”

The third contribution comes from WIR's authority as a highly respected UNCTAD publication. The Reports have worldwide dissemination to academics, practitioners, MNE executives, government policymakers, think tanks, NGOs, and the general public. The WIRs are well-written, with excellent visuals and tables, and are less technical than journal articles. The Reports are also up to date - both in data and analysis - of FDI statistics and policies. In other words, the Reports have clout and impact.

A fourth contribution that the WIRs have made is their singular (and to some extent unique) focus on developing countries. As a publication of UNCTAD, WIR is tasked with analyzing international trade and investment from the perspective of developing countries. IB scholars, attracted by the ready availability of US and OECD data, have conducted many if not most of their empirical studies using developed country samples. The rise of emerging markets and emerging market firms in the early 2000s broadened the range of countries studied but large segments of the world (e.g., Africa) have been mostly untouched by IB scholars.

\section{WHITHER WIR (REDUX)?}

My role on the “WIR@30” panel at the AIB 2020 (Virtual) Annual Conference, as requested by the panel chair, James Zhan, Director of DIAE, was to "think ahead" and identify what I saw as "key emerging issues for the future research and policy agenda of WIR." I interpreted this request as asking me to develop a list of possible theme chapters for the next 10 years of WIRs. My talk, "Lorraine's Wish List for 2021-2030," discussed 10 possible theme chapters.

This "wish list" has grown to a full baker's dozen based on conversations and emails with several individuals since the webinar. I mention a few. James Zhan, in separate correspondence (Sept. 7, 2020) with the author, noted that his criteria for selecting WIR themes over the years had included "topicality, feasibility, and sensitivity." Thus, WIR themes needed to be topical and feasible but also politically doable within the UNCTAD system. Peter Buckley's (2020a) discussion of WIR in the context of Big Questions and Grand Challenges led me to sort my list into his two categories. Discussions with Robert Grosse and Mira Wilkins led to my inclusion of the last topic on the world without a hegemon. See Table 1 for a list of the theme topics, which I briefly discuss below. 


\section{BIG QUESTIONS}

\section{DIGITAL ECONOMY FIRMS AND BUSINESS MODELS}

This theme chapter would build on WIR 2017 and WIR 2020 by treating the MNE (the enterprise) as the unit of analysis rather than FDI (the flow and stock) or international production (global value chains (GVCs)). We know that IB research questions can be addressed at various levels: micro (the MNE and its plants and affiliates), meso (the industry, GVCs), and macro (country). This would be a follow-up study to WIR 2017 and WIR 2020, with the same themes but the analysis at the MNE level, building my early work on this topic in Eden (2016). The theme chapter would look what I called "born digital" and "going digital" firms (Eden, 2016) and their strategies and structures. The chapter would focus on the economics of different digital business models: platforms, Internet of Things, 3D printing, and so on. Case studies of MNEs can be very helpful; it would be particularly appropriate and useful to look at some of the new digital economy MNEs and their activities in developing countries.

\section{CHANGING NATURE OF WORK IN THE DIGITAL ECONOMY}

Perhaps it is time now to look again at the changing nature of work, this time in the digital economy. Issues such as robotics and humans (are they complements or substitutes?), Artificial Intelligence, and 3D printing, warrant examination, along with their implications for white, blue, and pink collar jobs. This theme should follow the Digital Economy Firms and Business Models theme, moving from the firms and business models to explore implications for work.

\section{FACTFULNESS/BIG DATA}

WIR should examine the issue of data in the global economy: how data is created and used. What are the effects of data on developing countries and what are the policy implications? This would include issues such as "fake news", digital news platforms, and national security issues with data. It would be also useful to discuss the findings in Factfulness (Rosling, Rönnlund, \& Rosling, 2018) about how people misunderstand the facts because they do not understand the way the facts are presented, and how we might present them better. This would also include non-government sources of data (e.g., cell phone data) and how these nonapproved data sources might give us better data in real time (e.g., in terms of COVID-19) than existing national/international sources of data. This issue also applies to UNCTAD in terms of its own datasets which are more "macro" and "annual" in nature. This theme chapter follows logically in order after the first two themes.

\section{EVIDENCE-BASED POLICYMAKING (EBPM)}

From a policymaking perspective, a theme chapter on evidence-based policymaking, focusing on FDI and MNEs and what works and what does not work in developing countries would be a very useful topic. Exploring best practices in EBPM could be very useful for developing country govern- ments, especially if done in the context of the Sustainable Development Goals (SDGs) and FDI. Eden and Wagstaff (2020) on EBPM and SDG 5 Gender Equality provides a possible framework. I recommend including a variety of case studies of EBPM (both successes and failures) in developing countries. DIAE is already publishing reports using EBPM, for example, the Best Practices in Investment for Development Series, Investment Promotion Advisory Series, Investment Policy Review Series, and the Investment Policy Treaty Series. Insights from these series could be drawn together for a theme chapter in WIR.

\section{PRIVATE-PUBLIC PARTNERSHIPS (PPPS)}

The UN has recognized that many of the SDGs are unattainable without the cooperation of MNEs. Private-public partnerships involving national governments and private sector firms are recommended as a way to move the SDGs forward. A theme chapter on the topic of PPPs would therefore be useful and also fit within the context of the UN 2030 Agenda.

\section{SOCIAL RESPONSIBILITY OF BUSINESS}

This theme chapter would look at how business-society roles are changing in the global economy, particularly in the context of the UN 2030 Agenda for the SDGs. What is the social responsibility of MNEs in the digital economy that lies ahead? How is social responsibility different from CSR? Should taxation be included and if so, how? Are MNE-state relations likely to be more or less cooperative in a socially responsible world? What are the linkages between social responsibility, public-private partnerships, and economic development? Eden (2020) may provide some useful insights.

\section{GRAND CHALLENGES}

\section{SDGS 1 AND 10: POVERTY AND INCOME INEQUALITY}

One of the Grand Challenges of our time is the growing inequality inside country borders between rich and poor, whether measured by the GINI ratio or by access to basics such as health care, good education, and the Internet. Poverty (especially child poverty) within and across countries is another longstanding Grand Challenge. Both are identified as Sustainable Development Goals: Poverty (SDG 1) and Income Inequality (SDG 10). Coupling them together in a theme chapter focused on understanding the roles played by FDI and MNEs in ameliorating - and also exacerbating - poverty income inequalities within and across countries would be a difficult but critically important topic, one that I believe has not been addressed in previous WIRs.

\section{SDG 5: GENDER EQUALITY}

The 2030 Agenda is now even more important for economic development - and even harder to achieve - due to disruptions to the global economy caused by the COVID-19 pandemic. The success of the 2030 Agenda depended on sustained growth and globalization; both are now in tatters. While the WIRs have examined the SDGs already, at least two specific SDGs warrant highlighting as theme chapters 
for WIR. The first is SDG 5: Gender Equality (Eden \& Wagstaff, 2020). Women are being disproportionately and negatively affected by COVID-19, not only in the workplace (McKinsey \& Company, 2020) but also through a dangerous shadow pandemic of violence against women and girls (UN Women, 2020). This theme chapter would look at SDG 5 through the lenses of FDI and MNEs in the context of developing countries.

\section{SDG 13: CLIMATE ACTION}

The second SDG that warrants a theme chapter in WIR is climate change (SDG 13). WIR 2010 discussed FDI in a lowcarbon economy, but this was written before the SDGs. Climate change is so urgent that it deserves being addressed again - and sooner rather than later.

\section{FRAGILITY, CONFLICT, AND VIOLENCE}

Fragile and conflict-ridden states are failed states. Violent conflict is a critical development challenge, generating extreme poverty. International trade and FDI can be lifelines, lifting people out of poverty but can generate war and violence (e.g., conflict diamonds). Understanding how FDI and MNEs can be attracted into - and retained - in conflictridden states could be critically important for reducing extreme poverty.

\section{CORRUPTION}

A theme chapter addressing the interactions between corruption (pervasive and arbitrary), FDI and economic development would be an important - although controversial and probably politically impossible - theme chapter for WIR. The theme chapter would need to address both private and public sector corruption and its impact on FDI and development.

\section{SHOCKS AND RESPONSES IN A VUCA WORLD}

WIR 2020 is somewhat close to this theme. There are a variety of crises or shocks that can happen to the global economy: economic, political, technological and natural (COVID-19; climate change). Building on the VUCA (volatility, uncertainty, complexity, ambiguity) framework (Buckley, 2020b), I'd like to see more work on crisis and crisis management, applied to different types of crises, and then applying these theoretical lenses to FDI and MNEs in and from developing countries. While the content would most likely need to be conceptual rather than based on observed data, this could be a highly important theme for WIR, particularly given the current COVID-19 pandemic and global recession.

\section{A MORE PROTECTIONIST WORLD}

We are in a world very different from that of the second half of the $20^{\text {th }}$ century. In that earlier world the USA played the role of a "benevolent hegemon" (most of the time), fostering world trade and FDI, and participating in and supporting international organizations. International organizations - the World Bank, IMF, WTO - flourished and inter- national trade and FDI agreements multiplied, liberalizing and connecting economies. MNEs engaged in complex integration strategies building dense networks of global value chains, promoting globalization and lifting millions out of poverty. Since the early 2000 s, however, triggered by the 2007-2008 financial crisis, we have seen a rising backlash against globalization, conflicts among Great Power states (especially the United States and China), and a move to more protectionist industrial policies. What are the implications for developing countries, particularly the smallest and poorest, in this more protectionist and conflictual world; what room do they have to maneuver? Differences in country size and resources matter; China and India have very different options than small African or Latin American states. Industries also matter. For example, in the energy sector (mining, oil, lithium mining, electric batteries, wind power), should state-owned MNEs be treated the same as privately held MNEs when a small developing country is bargaining with MNEs over concessions? Addressing the role for the smallest and least developed of the developing countries in a more protectionist and conflictual world is my last recommended theme chapter.

\section{CONCLUSIONS}

Anniversaries are times to celebrate, throw a party, and recognize the exceptional individuals and events that happened in the past. Anniversaries are also useful for taking stock of where an organization or institution is now and to look ahead at where it can and should be moving. My assessment is that UNCTAD's Division of Investment and Enterprise can be justly proud of what it has accomplished with the World Investment Report during its first 30 years. The WIR's success comes from its four core strengths: unique surveys and datasets, IB scholar-DIAE knowledge sharing, global reach, and focus on developing countries. My list of possible themes for the next 10 years of WIR is designed to stimulate discussion and perhaps some research by IB scholars on these critically important topics. My recommendation for DIAE and WIR: "Full steam ahead!"

\section{ACKNOWLEDGEMENTS}

This paper is based on my presentation at the Academy of International Business (AIB) 2020 Virtual Conference on 7 July 2020 in the session “World Investment Report @30: Investment and Sustainable Development.” I thank James Zhan, Robert Grosse, Peter Buckley, Mira Wilkins, John Mezias, and Bill Newburry for comments and discussions that helped to shape this paper. Responsibility for any errors or omissions is my own.

\section{ABOUT THE AUTHOR}

Lorraine Eden (leden@tamu.edu) is Professor Emerita of Management and Research Professor of Law at Texas A\&M University. She received her $\mathrm{PhD}$ with Distinction in Economics from Dalhousie University. She has been Editor-in- 
Chief of JIBS, President of AIB, and is currently Dean of the AIB Fellows. Her current research interests include transfer pricing, MNE-state relations, and shocks and responses.

This is an open-access article distributed under the terms of the Creative Commons Attribution 4.0 International License (CCBY-4.0). View this license's legal deed at http://creativecommons.org/licenses/by/4.0 and legal code at http://creativecommons.org/licenses/by/4.0/legalcode for more information. 


\section{REFERENCES}

Buckley, P. J. 2020a. International Business Research and the World Investment Report: "Big Questions" and Grand Challenges. AIB Insights, 20(4).

Buckley, P. J. 2020b. The theory and empirics of the structural reshaping of globalization. Journal of International Business Studies. https://doi.org/ 10.1057/s41267-020-00355-5.

Buckley, P. J., Doh, J. P., \& Benischke, M. H. 2017. Towards a renaissance in international business research? Big questions, grand challenges, and the future of IB scholarship. Journal of International Business Studies, 48(9): 1045-1064.

Eden, L. 1996. Whither WIR? Transnational Corporations, 5(2): 145-156.

Eden, L. 2016. Multinationals and Foreign Investment Policies in a Digital World. The e15 Task Force on Investment Policy. World Economic Forum and the International Centre for Trade and Sustainable Development. February. http://e15initiative.org/publi cations/multinationals-and-foreign-investment-polic ies-in-a-digital-world/.

Eden, L. 2020. The Social Responsibility of Multinationals - From an After-Thought to Center Stage. In B. Schlegelmilch \& I. Szőcs (Eds.), Rethinking Business Responsibility in a Global Context - Challenges to Corporate Social Responsibility, Sustainability and Ethics. Springer Series: CSR, Sustainability, Ethics \& Governance.
Eden, L., \& Wagstaff, M. F. 2020. Evidence-Based Policymaking and the Wicked Problem of SDG 5 Gender Equality. Journal of International Business Policy. https://bit.ly/3eZNACD.

McKinsey \& Company. 2020. Women in the Workplace, 2020. https://www.mckinsey.com/feature d-insights/diversity-and-inclusion/women-in-the-wo rkplace.

Miroux, A. 2020. UN and business: The WIR prequel. AIB Insights, 20(4).

Rosling, H., Rönnlund, A., \& Rosling, O. 2018. Factfulness: Ten Reasons We're Wrong About the World-and Why Things Are Better Than You Think. Flatiron Books.

Sauvant, K. P. 2020. The WIR at 30: Contributions of the WIR to global and national investment policy making. AIB Insights, 20(4).

UN Women. 2020. COVID-19 and Ending Violence Against Women and Girls. April. https://www.unwom en.org/en/digital-library/publications/2020/04/issuebrief-covid-19-and-ending-violence-against-womenand-girls.

UNCTAD. 2019. Results and Impact Report 2019: Division on Investment and Enterprise. Geneva: UNCTAD.

Zhan, J. 2020. The WIR@30: Paradigm Shift and a New Research Agenda for the 2020. AIB Insights, 20(4). 


\section{SUPPLEMENTARY MATERIALS}

eden_web_appendix.pdf

Download: https://insights.aib.world/article/18029-whither- wir -redux/attachment/47087.pdf 